\section{Carcinoid tumour of the breast}

Carcinoid tumours are normally found in the gastrointestinal tract and occasionally in the lung. A carcinoid in the breast does not appear to have been reported.

\section{Case report}

A 66-year-old woman was referred with a two-week history of a lump in her left breast. This had not changed in size, nor was there any associated pain or nipple discharge. She was otherwise fit and well and had suffered no illnesses of note. There was a mobile lump, $2 \mathrm{~cm}$ in diameter with a smooth surface, in the upper and outer quadrant of her left breast. There were no other abnormalities and no palpable axillary lymph nodes. She was admitted to hospital and the lump excised. The surgeon noted that the lump was solid and yellow with a necrotic centre. Histological examination showed a typical carcinoid tumour containing argentaffine cells (figure). The results of urinary 5-hydroxy indole-acetic acid assays were normal. She remained well 12 months after removal of the tumour and the results of further 5-hydroxy indole-acetic acid assays remain normal.

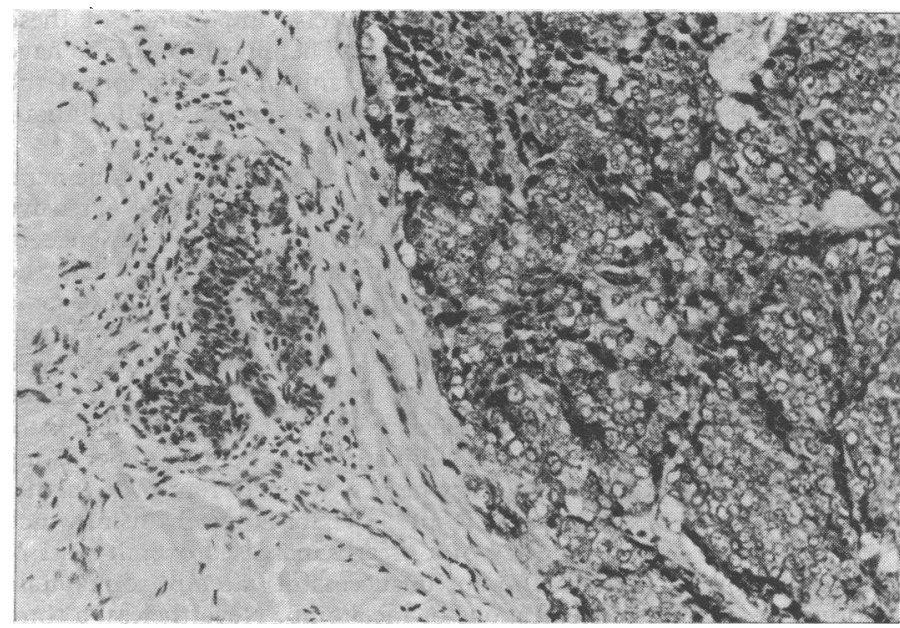

Clumps of argentaffine cells in tumour abutting normal breast tissue.

\section{Comment}

Carcinoid tumours occur mainly in the gastrointestinal tract, most being found in the small intestine and the appendix. They are also found in the lung, being the commonest form of bronchial adenoma. Those in the appendix are usually benign, while the jejuno, ileal, and the colonic tumours are frequently malignant, the last behaving like an adenocarcinoma. The tumours arise submucosally and protrude into the lumen of the bowel often causing obstruction. Obstruction may also result from the tumour's extending serosally and producing a dense fibrotic reaction with subsequent adhesion of surrounding bowel.

Many carcinoids are found incidentally at necropsy. They are seen at all ages, and necropsy findings indicate that they are probably much commoner than would appear from clinical practice. Berge and Linell ${ }^{1}$ concluded that, as this type of tumour was so common, people died with their tumour and not because of it. When the tumour metastasises usually it is to the liver and lymph nodes. Metastases have also been recorded in the skin, bone, brain, myocardium, peritoneum, kidney, adrenal, and spleen. No mention of a tumour of the breast, either primary or metastatic, has been found. The carcinoid syndrome is relatively uncommon in comparison with the frequency of the tumour. It is usually seen with tumours outside the portal circulation or, when there are hepatic metastases, it may be produced by tumours at any site.

Treatment of carcinoid tumour is the same as for any benign or malignant tumour of the gastrointestinal tract. ${ }^{2}$ After local excision for carcinoid of the appendix Moertel $^{3}$ had no fatalities. Hepatic metastases should be excised if possible, especially if the patient has the carcinoid syndrome, and the patient may then remain free of symptoms for many years. The patient described here is free of symptoms 12 months after removal of her tumour and she has apparently no other possible primary focus for it. So far, therefore, it must be assumed that this was a primary carcinoid tumour of the breast.

I thank Mr C Kirkham for permission to report this case.

${ }^{1}$ Berge, T, and Linell, F, Acta Pathologica et Microbiologica Scandinavica, $1976,84,322$

${ }^{2}$ Morgan, J G, Marks, C, and Hearn, D, Annals of Surgery, 1974, 180, 720.

${ }^{3}$ Moertel, C G, Dockerty, M B, and Judd, E S, Cancer, 1968, 21, 270.

(Accepted 21 April 1978)

Battle Hospital, Reading, Berks RG3 1AG

$P$ G DEVITT, FRCS, surgical registrar (now lecturer in surgery, University of Bristol, at Southmead General Hospital)

\section{Hyperparathyroidism after radiotherapy}

In 1975 Rosen et al ${ }^{1}$ proposed a relationship between radiation of the head and neck region in childhood and late development of hyperparathyroidism. We describe a patient treated with radiotherapy in childhood for tuberculous node disease in the neck who presented with hyperparathyroidism 60 years later.

\section{Case report}

A 66-year-old man underwent external radiation therapy to the right side of his neck for tuberculous lymph nodes when he was 5 years old. The course of treatment, he stated, lasted for about six months.

In 1955, when he was aged 46, he was first seen because of a thyroid swelling. His general condition was excellent. On the right side of his neck there was considerable tissue loss, skin atrophy, pigmented scars, and the telangiectasia of irradiation. The skin was hypersensitive. The thyroid swelling was smooth, soft, and about twice the size of a normal gland. In the right submental region there was an oval swelling, $1.5 \mathrm{~cm}$ in diameter, and a needle biopsy specimen showed it to be inflammatory. In the right posterior triangle there was another rounded mobile swelling, which had been present for eight years; a biopsy specimen proved it to be a neuroma. The thyroid enlargement was diagnosed as a simple goitre. Thyroxine $0.2 \mathrm{mg}$ daily was prescribed. The patient attended annually because of the possibility of neoplasia occurring in the thyroid or salivary glands due to previous radiotherapy.

In February 1975 he was admitted to hospital with rapid atrial fibrillation as an emergency case. Investigation showed hypertension and raised serum calcium concentration. Subsequent investigations showed serum calcium $2 \cdot 9-3.08 \mathrm{mmol} / 1 \quad(11.6-12.32 \mathrm{mg} / 100 \mathrm{ml})$ (normal $2 \cdot 15-2.65 \mathrm{mmol} / 1 \quad(8 \cdot 6-$ $10.6 \mathrm{mg} / 100 \mathrm{ml})$ ); serum phosphate $0.45-0.8 \mathrm{mmol} / 1(1.39-2.5 \mathrm{mg} / 100 \mathrm{ml})$ (normal $0 \cdot 8-14 \mathrm{mmol} / 1(2 \cdot 5-43.3 \mathrm{mg} / 100 \mathrm{ml})$ ); urine calcium total output $13.7 \mathrm{mmol}(548 \mathrm{mg}$ ) (normal up to $5 \mathrm{mmol}(200 \mathrm{mg})$ ); plasma creatinine $146 \mu \mathrm{mol} / 1$ (1.7 mg/100 ml) (normal $55-125 \mu \mathrm{mol} / 1(0 \cdot 6-1.4 \mathrm{mg} / 100 \mathrm{ml})$ ). Skeletal radiographs including hands and skull showed no evidence of hyperparathyroidism. An intravenous pyelogram was normal.

The neck was explored for hyperparathyroidism in July 1975. On the irradiated right side both parathyroids were larger than normal and they were removed. One weighed $610 \mathrm{mg}$, the other $170 \mathrm{mg}$ (normal $40 \mathrm{mg}$ ). Histological examination of both showed cystic hyperplasia. The right thyroid lobe seemed normal, but the left was nodular and extended retrosternally and was surrounded by dense adhesions. The parathyroids were not identified on the left side, and partial thyroidectomy was performed. Histological examination showed a colloid goitre. After operation serum calcium and inorganic phosphate concentrations returned to normal. Followup showed no evidence of recurrence of hyperparathyroidism. 